\title{
La Procesión del Corpus Christi en Cartagena de Indias: Orden y Representación Social en la fiesta barroca
}

Manuel Serrano García ${ }^{l}$

\section{RESUMEN}

Las festividades y ceremonias barrocas tenían una doble dimensión: religiosa y civil. Por un lado, servían para celebrar y recordar unos principios religiosos y, por otro, era una forma de hacer visible el orden social y político. Ambos principios coexistían bajo unas mismas formas que la fiesta barroca trasmitía a la mayor parte del pueblo. Las fiestas del Corpus Christi fueron el mejor medio de representación político-religiosa que hubo en el mundo hispánico. El estudio de la festividad del Corpus Christi en Cartagena nos permite hacer una reconstrucción de esta festividad, analizando la riqueza simbólica y social que se desplegaba. La festividad era también un espejo social donde se reflejaban las tensiones entre las distintas instituciones participantes y las consecuencias sociales que implicaba tan compleja representación.

Palabras clave: Cartagena de Indias, festividad del Corpus Christi, cabildo eclesiástico, cabildo secular, fiestas coloniales.

\section{"The Corpus Christi Procession in Cartagena de Indias: order and social status in this counter-.reformation festivity."}

\section{Abstract}

The counter-reformation festivals and ceremonies included a double purpose, they were both religious and social occasions. On the one hand they operated as vehicles to celebrate and remind the faithful of religious principles and, on the other hand, they were a means to make the political and social orde visible. Both these principles were contained in this same counter-reformation festivity that was transmitted to the majority of the people.The Corpus Christi festivities turned out to be the best political and social means of representation in the Hispanic world. Research on the Corpus Christi festivities in Cartagena de Indias allows us to rebuild this particular festivity, analyzing the richness of symbols and social display. This

\footnotetext{
${ }^{1}$ Doctor en Historia. Universidad de Granada. Profesor enseñanza secundaria San Juan de Dios, $\mathrm{n}^{\circ} 33^{\circ} \mathrm{D}, 18220$

Albolote (Granada, España) +34 636952980 manuelserrano13@gmail.com
} 
festivity is also a reflection of the social tensions among the different institutions that participated and the social consequences that such a complex representation implied.

Key word : Cartagena de Indias, Corpus Christi festivities, council of canons, city council, colonial festivities.

Recibido: 28 de septiembre de 2017

Aceptado. 05 de febrero de 2018

\section{Introducción}

Hasta la fecha hay poca documentación localizada que haga referencia a la celebración de la festividad del Corpus Christi en Cartagena de Indias. A diferencia de otras ciudades, que han conservado más documentación proveniente de sus archivos municipales, poco se ha podido escribir del Corpus de Cartagena. La documentación que se ha localizado responde en su mayoría a pleitos y problemas que saltaron de la ciudad a instituciones de gobierno superiores, Audiencia de Santafé y Consejo de Indias. A pesar de ello, es posible trazar los rasgos principales de esta celebración en Cartagena a lo largo del periodo colonial. El tipo de documentación permite mostrar otros rasgos de la celebración, a parte de los descriptivos de su composición, lo que permite entrever los condicionantes sociales y políticos de la celebración.

La celebración del Corpus Christi era la fiesta que condensaba de manera más clara los principios del barroco, entendido en el sentido amplio que usa José Antonio Maravall para definir una época. En este sentido, a nadie se le escapa que la festividad cumple con todos los principios definitorios de la cultura del Barroco: su marcado carácter sugestivo orientado a persuadir y convencer, un sentido masivo y urbano al aglutinar a todos los elementos sociales en una misma celebración pero no de una manera igualitaria, sino muy al contrario para marcar las diferencias de sociales sobre las que se sustentaba el poder político. ${ }^{2}$

La festividad del Corpus Christi tiene un origen medieval, instaurada por el papa Urbano IV en 1264 para fomentar el culto al Santísimo Sacramento. Fomentada por sucesivos pontífices, la fiesta se fue desarrollando por diversas ciudades de Centroeuropa hasta que el

\footnotetext{
${ }^{2}$ José Antonio Maravall, La cultura del Barroco. Análisis de una estructura histórica, Barcelona, Ariel, 1975.
} 
papa Juan XXII institucionalizó la procesión con la Sagrada Forma y las fiestas litúrgicas de la octava del Corpus. Pronto la fiesta se extendió por todo el orbe católico, en la península Ibérica y especialmente en los territorios andaluces, recién recobrados para la cristiandad. De allí pasó a los nuevos territorios americanos, cobrando nueva fuerza como medio catequizador de las nuevas poblaciones y confirmador de la presencia de las autoridades españolas. Desde un principio, la fiesta contó con una parafernalia profana que recogía tradiciones locales que se fueron incorporando al cortejo, confiriéndole un carácter profano que rápidamente quedó integrado en una procesión cívico-religiosa de gran popularidad. La Contrarreforma católica revitalizó la fiesta añadiendo más boato y simbolismo para reafirmar la presencia real de Cristo en la Eucaristía, negada por la Reforma protestante. En América la fiesta recobró un nuevo sentido por el que la monarquía mostraba su triunfo sobre el paganismo indígena, al mismo tiempo que la liturgia civil y religiosa reafirmaba un orden político sancionado por la propia divinidad.

La procesión mostraba el triunfo de la Iglesia sobre el pecado, la herejía y el paganismo, de ahí que participara toda la población y tuviera un marcado carácter cívico al desfilar también todas las organizaciones sociales, tanto laicas como religiosas, y, por supuesto, las autoridades civiles como brazo secular. Esta compleja representación fue difícil de organizar y desde la Corona se dio suma importancia a un cortejo tan cargado de simbolismo. La regulación de la fiesta fue muy tenida en cuenta, por lo se produjo una destacada legislación donde se establecía el orden, el papel de cada participante y todo lo relativo a la puesta en escena. Como en otros casos, la costumbre tenía demasiado peso y todo se sostenía sobre un difícil equilibrio donde cada uno tenía que desempeñar un papel al que no siempre se atenía. El enfrentamiento entre autoridades civiles y religiosas fue común en una clara pugna por demostrar la prevalencia de una institución sobre la otra. En consecuencia, fue regulado una y otra vez por las instituciones de gobierno, tanto Consejos como Audiencias, con la finalidad de dar un claro mensaje del orden político que debía prevalecer. Unas cuestiones que no estuvieron restringidas a los territorios americanos sino que las encontramos en muchas ciudades peninsulares donde las tensiones entre los poderes religiosos y civiles relucían con la misma fuerza que en los territorios americanos. También ayudaba el hecho de que la fiesta fuese organizada y costeada principalmente por sectores civiles de la ciudad, en concreto, 
por los cabildos seculares, mientras que los aspectos litúrgicos quedaban en manos del clero, lo que conllevaba numerosos roces entre dos grupos que se sentían partes fundamentales de la festividad. Al mismo tiempo, la celebración era un perfecto escaparate social, en el que ninguno de los participantes estaba dispuesto a ceder su puesto a otro por el contenido simbólico que esto conllevaba. Por tanto, la festividad se convirtió en un escenario más de la rivalidad entre los cabildos secular y eclesiástico, entre la preeminencia de los poderes cívico y religioso, corporaciones de distinta naturaleza pero con un mismo ámbito de actuación y de representación. Se pretencía sobre todo dar un mensaje claro de la unidad católica y del orden social que la monarquía hispánica representaba.

\section{El Corpus Christi en Cartagena}

La celebración del Corpus Christi comenzó con los primeros años de vida de la ciudad, incluso antes de la erección canónica de la sede. La devoción al Santísimo sacramento llegó de la mano de los primeros conquistadores y sus capellanes, estableciendo para su adoración sagrarios en los primitivos templos. Es justo en este primer momento cuando encontramos la primera referencia a la celebración del Corpus, cuando en junio de 1536, durante la fiesta, se colocó al Santísimo en el sagrario de la catedral. La primitiva catedral de Cartagena, a pesar de ser de paja, contaba con un sagrario en forma de caja de plata, bajo dosel y cubierto por un guardapolvo carmesí. ${ }^{3}$ Desde un primer momento, la presencia del Santísimo cobra un claro sentido simbólico en el establecimiento de la nueva religión y comienzo de un nuevo orden sancionado por la divinidad que protege a los nuevos pobladores españoles, así lo expresaba el licenciado Juan Vadillo al decir que "desde aquel tiempo acá parece que todo está alegre, e Dios envía los tiempos con toda templanza y salud". ${ }^{4}$ En estos primeros momentos la fiesta no debería diferir demasiado de la forma en la que se celebraba en otras poblaciones, como por ejemplo Tunja, donde en 1571 ya encontramos todos los elementos

\footnotetext{
3 Juan Manuel Pacheco, "Historia eclesiástica. La evangelización del nuevo mundo", en Historia extensa de Colombia, vol. XIII, t. I, Bogotá, ediciones Lerner, 1971, p. 152

${ }^{4}$ J. M. Pacheco, "Historia eclesiástica. La evangelización del nuevo mundo", p. 396. Recogido a su vez de Colección de documentos inéditos relativos al descubrimiento, conquista y organización de las antiguas posesiones españolas de América y Oceanía, Primera serie, t. 41, Madrid, 1864, p. 412. Carta al rey, Cartagena 15 de octubre de 1537.
} 
de la celebración. ${ }^{5}$ En el siglo XVII, una vez celebrado el Concilio de Trento (1545-1563), la fiesta alcanzaría mayor complejidad y solemnidad. Así pues, durante el gobierno de fray Juan de Ladrada, según recoge Alonso de Zamora, ${ }^{6}$ se procedió a fomentar el culto al Santísimo Sacramento, en concreto, dotó de solemnidad la salida del viático al hacer acompañar de palio y música de chirimías. ${ }^{7}$ De ello se desprende que el culto sacramental estaba algo descuidado en la ciudad, una cuestión a la que hacen referencia también prelados posteriores. Las hermandades sacramentales eran las encargadas de fomentar el culto eucarístico y radicaban en las parroquias. La hermandad sacramental debió constituirse durante el siglo XVII, sin embargo, no es hasta la siguiente centuria cuando gozó de mayor esplendor. Se encargaría del culto sacramental a lo largo de todo el año, organizando las salidas del viático para visitar enfermos así como las festividades propias con procesiones por el interior del templo conocidas como de Minerva. El culto al Santísimo Sacramento no contó con el patronazgo de los monarcas Austrias, muy devotos de la hostia consagrada. El uso del término "Su Divina Majestad" da entender la importancia que tenía la presencia de la hostia consagrada entre las gentes. Su presencia no solo era reverenciada sino que se tenía como la máxima autoridad moral ante la cual se sofocaban los tumultos y era la mayor garantía de respeto del pacto. ${ }^{8}$ La devoción entre los españoles era grande, remedio de males y protector frente a catástrofes, ${ }^{9}$ los desacatos y profanaciones eran duramente castigados.

Sin embargo, la festividad del Corpus Christi sí gozó de gran popularidad, que hay que desvincular de la devoción, pues partía de la oficialidad y obligaba a la participación de toda

\footnotetext{
${ }^{5}$ A la celebración acudían todos los vecinos blancos tanto de la ciudad como de las estancias, participaba también el cabildo, los gremios, los indios con sus pendones, los estandartes de las cofradías y los grupos de danzas. J. M. Pacheco, "Historia eclesiástica. La evangelización del nuevo mundo", p. 398.

${ }^{6}$ Alonso de Zamora, Historia de la provincia de San Antonio del Nuevo Reino de Granada, Bototá: A.B.C., 1945 , t. II, p. 60.

${ }^{7}$ Con el término chirimías se identifica instrumentos, tanto melódicos como de percusión, de la costa Atlántica. Camila Aschner Restrepo, "La música en las Fiestas y Celebraciones del Caribe colombiano, siglos XVII y XVIII", en Memoria y Sociedad, vol. 9, n. 18, 2015, p. 80.

${ }^{8}$ Son muchos los ejemplos del uso del Santísimo Sacramento en circunstancias delicadas, por ejemplo la revuelta popular del Corpus de México en 1692 solo fue aplacada con la presencia de la Eucaristía. Linda Curcio-Nagy, "Giants and Gypsies: Corpus Christi in Colonial México City", en William H. Beezley, Cheryl English Martin y Willian E. French (eds.) Rituals of Rule, Rituals of Resistence. Public Celebrations and Popular Culture in Mexico, SR. Books, Wilmington, Delaware, 1994, p. 19. En la revuelta de la tropa de Cartagena de 1745, los rebeldes solo confiaron en el perdón y olvido si se hacía con su Divina Majestad presente. Juan Marchena Fernández, "Sin temor de rey ni de Dios. Violencia, corrupción y crisis de autoridad en la Cartagena colonial", en J. Marchena y A. Kuethe (eds), Soldados del rey. El ejército borbónico en América Colonial en vísperas de la independencia, Universidad Jaime I, Castellón, 2005, p. 70.

${ }^{9}$ Son muchos los ejemplos que al respecto recoge la obra, de marcado carácter confesional, de Constantino Bayle, S.J., El culto al Santísimo en Indias, CSIC, Madrid, 1951, p. 651.
} 
la sociedad como miembros de un solo cuerpo social. El ambiente festivo que llevaba aparejado le aseguraba una mayor adscripción popular.

Desgraciadamente no se ha hallado suficiente documentación como para hacer una reconstrucción total de la festividad del Corpus en Cartagena. Como en otras ciudades hispanas constituyó la principal festividad al conjugar los elementos populares, religiosos y civiles. Las festividad tenía dos vertientes que se mezclaban y complementaban: una profana y otra religiosa, a lo que habría que unir una política. La poca documentación conservada nos permite solo reconstruir la fiesta parcialmente, aunque en todas las sedes diocesanas se siguen los mismos esquemas..$^{10}$ La fiesta tenía su epicentro en la catedral donde se celebraban las Vísperas previas a la festividad litúrgica con los rezos correspondientes, la exposición del Santísimo, donde concurrían el clero catedralicio y el cabildo secular con el gobernador a la cabeza. Paralelamente se realizaban danzas y bailes en torno al templo y llegado el momento podían continuar en el interior. A la mañana siguiente se realizaba la procesión por las calles con la forma consagrada bajo palio - portado por los regidores de la ciudad- a la que acompañaban los seglares pertenecientes a cofradías, clero regular, secular, cabildo catedral, cabildo de la ciudad y representación militar. A ellos se sumaban todas las organizaciones civiles de la ciudad, gremios, justicias, y demás instituciones, incluso representaciones de grupos étnicos, aunque no se ha podido encontrar referencias a ello para Cartagena. Finalmente, se sumaban los elementos más festivos como las danzas y personas disfrazadas. No conocemos el recorrido exacto del discurrir de la procesión, solo que salía de la catedral y se dirigía hacia la plaza de Santo Domingo, ${ }^{11}$ pero debió ser en torno a los principales lugares de poder simbólico y real de la ciudad: catedral, casas del cabildo e Inquisición, en una manera de sacralizar el espacio urbano, lo que quedaba acentuado por la instalación de altares donde se hacían estaciones con oraciones de adoración. Posteriormente se

\footnotetext{
${ }^{10}$ Por ejemplo, se han conservado las actas de cabildo de México en el que se detalla el orden y composición de la procesión. Nelly Sigaut, "Corpus Christi: la construcción simbólica de la ciudad de México", en Víctor Mínguez (ed.), Del libro de emblemas a la ciudad simbólica, vol. I, Castellón, Univerisitat Jaume I, 2000, p. 39.

${ }^{11}$ Desde allí debía continuar por la calle Virgen del Carmen y girar buscando los edificios de la Inquisición y de las casas del cabildo, por lo que podría entrar de nuevo al templo por la puerta lateral. No obstante, el recorrido pudo ser modificado a lo largo de los años.
} 
desarrollaba la Octava donde se repetía el esquema de celebración litúrgica en el interior del templo con una procesión y manifestaciones festivas en la ciudad.

Las primeras noticias sobre la organización de la celebración las encontramos con el obispo fray Diego Torres Altamirano en 1620 cuando se reorganizó la procesión dotándola de una mayor solemnidad y representatividad. Hasta el momento, el obispo había notado que en la procesión no se seguía el orden en el discurrir del cortejo con lo que quedaba bastante deslucido. Siguiendo el memorial del papa Clemente VIII (1600), y como se usaba en las iglesias metropolitanas y españolas, debía estar encabezada por las cofradías de seglares con sus estandartes, seguidas por orden de antigüedad por las órdenes religiosas, precedidas con su cruz correspondiente con manguilla y sus prestes con capa. Primero iría la orden de la Merced por el lado izquierdo y en paralelo los agustinos, tras ellos franciscanos y dominicos respectivamente. ${ }^{12}$ Por último, le tocaba al clero secular, con todos los clérigos desde prima tonsura hasta el presbiterado con sobrepelliz y los de menores con bonete. Todo ello con la prevención de sanción con multa de cuatro pesos para el clero y seis para las cofradías. El obispo fray Diego de Torres y Altamirano provenía de Lima y había sido guardián de varios conventos en Andalucía donde fue provincial de Granada, lugares donde debió conocer de primera mano el boato y solemnidad con que se celebraba la festividad del Corpus Christi. Debió quedar muy impresionado por el desorden que reinaba en la procesión de la ciudad, no acostumbrada al boato de otras ciudades. Los seglares iban mezclados con los religiosos quienes no llevaban ningún orden y sin guardar la compostura necesaria. Tampoco era ajeno al significado catequético que el orden tenía: “[...] que en semejantes actos se debe tener especialmente en esta ciudad y tierra que por ser nueva se debe hacer con mucha más devoción por la edificación de los naturales."13

No obstante, a pesar de los desvelos del prelado la procesión siguió discurriendo como hasta el momento se había desarrollado. Los religiosos acudieron sin las cruces ni las capas, haciendo caso omiso a todo lo dictaminado al ir revueltos unos con otros. La importancia

\footnotetext{
${ }^{12}$ Hay que hacer notar que los jesuitas no participaban de la procesión por depender directamente del papa y por tanto no estar bajo la autoridad del obispo.

${ }_{13}$ Archivo General de Indias (Sevilla, España) (AGI), Santa Fe, 228, n. 78 a. El obispo fray Diego Torres Altamirano al rey, Cartagena, 18 de junio de 1620.
} 
dada a la distribución dentro del cortejo venía a significar el orden y el papel que tenía cada uno en la organización de la Iglesia, fieles, órdenes religiosas y clero secular, unidos bajo la presidencia del ordinario de la sede. No obstante, el incumplimiento de la normativa también dejaba claro un mensaje para el obispo, las órdenes religiosas no iban a transigir con unas medidas que no habían acordado y en las que hasta el momento no habían reparado. La independencia en el actuar de los religiosos demuestra las resistencias del clero regular frente a la autoridad de los obispos.

Debemos entender que cualquier actitud desarrollada durante el cortejo tenía un claro mensaje. El protocolo y el orden era una manera de significar el papel desempeñado por cada institución, de ahí que cualquier cambio fuera inspeccionado por si pudiera acarrear alguna modificación del statu quo. Así lo vemos en la intención del provisor del obispado de llevar un lugar reservado en las procesiones. En las procesiones de Semana Santa, pretendió acudir con el resto del tribunal eclesiástico entre las Justicias reales y el regimiento de la ciudad. Las intenciones del provisor no podían ser más claras: equiparar el tribunal eclesiástico al civil. Además la procesión del Corpus también conllevó una novedad que venía también a exaltar la jurisdicción eclesiástica, al hacerse acompañar el obispo con silla de manos portada por criados tras él. El cabildo de la ciudad protestó por ambas novedades, especialmente por la actitud del provisor quien pretendía hacer "cuerpo de tribunal". ${ }^{14}$ Obtuvieron lo demandado al recordar al provisor que su cometido en las procesiones era velar por su buen orden, y al obispo que el privilegio de la silla nunca se había visto en los territorios indianos. Sin embargo, y a pesar de haberse expedido cédulas con el mismo tenor, ${ }^{15}$ el obispo no acató la sentencia debiendo de hacer uso de la silla. En 1672 volvió a recibir una cédula en los mismos términos que la anterior, cuestión a la que tuvo que acceder no sin advertir que tenía todavía la causa recurrida ante el Consejo de Indias y la Chancillería de Granada. ${ }^{16}$

\section{Los elementos de la fiesta}

\footnotetext{
${ }^{14}$ José P. Urueta, Documentos para la historia de Cartagena, vol. IV, Cartagena, Tipografía de Antonio Araujo L., 1887-1891, doc. 467, p. 5.

15 J. P. Urueta, Documentos para la historia de Cartagena. Real Cédula, Madrid 24 de febrero de 1668, la reina gobernadora, p. 11.

${ }^{16}$ J. P. Urueta, Documentos para la historia de Cartagena. Obedecimiento de Sr. Obispo de Cartagena, p. 14.
} 
La festividad del Corpus se basaba en la conjunción de unos elementos que debía permanecer en un equilibrio que demostrara la paz social que con la que la Monarquía regía sus dominios. De ahí la conjunción de los representantes civiles con el gobernador a la cabeza, el obispo como pastor de la ciudad, encargado de portar a Dios en la custodia, y el pueblo/súbditos que formaban el cuerpo que debía adorar a la divinidad.

La presencia de las autoridades civiles era fundamental en la fiesta, especialmente la del gobernador que, como hemos comprobado, acudía como vicepatrono, es decir, representante del rey haciendo de esta manera visible su presencia en la lejanía de la colonia. Por ello, estaban bien regulados todos los honores que se le debían tributar y el papel que debía jugar en las celebraciones litúrgicas, desde el lugar que debía ocupar en el interior del templo hasta la asistencia a las celebraciones religiosas. De igual manera, le acompañaba el cabildo de la ciudad siempre con carácter de corporación, nunca como individuos. El ceremonial estaba igualmente regulado, de ahí que acudieran, precedidos por los maceros y abandonaran de igual forma el templo como una única organización. Gobernador y cabildo estaban obligados a acudir al templo mayor en las fiestas obligatorias (de tabla) que la Iglesia y la Corona habían establecido. Por último también acudían las Justicias reales y una representación del regimiento de la ciudad.

Dentro del templo se desplegaba un ceremonial donde cada institución tenía su lugar reservado, una jerarquía espacial del recinto sagrado que se correspondía con el grado de representación de la figura real, representada por el gobernador y el obispo, cuya importancia venía marcada por la cercanía al presbiterio. ${ }^{17}$ Los miembros del cabildo junto con el gobernador se situaban en el lado derecho (si nos situamos en el presbiterio) conocido como nave del Evangelio, de mayor importancia ritual. El clero si era celebrante se situaba en el presbiterio, como únicos a los que les estaba reservado el contacto con la divinidad y, si no celebraban, se situaban en el coro, situado frente al presbiterio en la nave central. ${ }^{18}$ Solo el

\footnotetext{
17 Eugenia Bridikhina, Theatrum mundi: Entramados del poder en Charcas colonial, Lima (Perú)/La Paz (Bolivia) Instituto Francés de Estudios Andinos, Plural editores, 2007, p. 295.

${ }^{18}$ La situación del coro frente al presbiterio es común en las catedrales españolas, dividiendo de este modo la nave principal en dos, en la de Cartagena estuvo situado hasta 1642 entre el cuarto y quinto pilar, adelantándose
} 
gobernador y obispo tenían sillas, el resto del cabildo usaba bancos, mientras que los fieles se mantenían de pie. ${ }^{19}$ Se buscaba de esta manera una cercanía con lo sagrado, no personal sino corporativa, en la medida en que se participaba de la representatividad del Rey, es decir, a mayor grado de representatividad más cercanía a la divinidad, salvando el espacio destinado a clero para poder desempeñar el ministerio sagrado. ${ }^{20}$ Además el gobernador, como vicepatrono real, podía usar un cojín y una alfombra a los pies de la silla. Un equilibrio simbólico muy difícil de mantener cuando uno de los actores se sobrepasaba en el celo de sus prerrogativas. El gobernador asistía con el cabildo a las vísperas del Corpus ocupando su lugar determinado donde había hecho colocar la silla con tapetes, y almohada a los pies. El cabildo se situaba en sus escaños ordenados por antigüedad. El obispo presidía desde el coro, con silla y cojín. Cuando se descubrió el Santísimo, gobernador y cabildo se pusieron de rodillas, lo cual fue reprendido por el obispo a través del maestro de ceremonias y pertiguero que reclamaron la retirada del cojín. Ante la negativa, mandó de nuevo el obispo al pertiguero quien después de hablar el gobernador, transmitió al obispo la queja del gobernador por haberle recriminado un gesto en medio de un acto público y no en privado antes de la ceremonia. En consecuencia, el gobernador abandonó el templo junto con el cabildo. Sin embargo, al momento de pasar frente al coro salió el obispo e increpó al gobernador hasta llegar a sujetarle con las manos y tener que intervenir el cabildo para evitar mayor desorden en el templo. ${ }^{21}$

\footnotetext{
en ese año a los siguientes pilares, frente a las puertas laterales. La modificación le valió la desaprobación real que mandó su restitución al lugar original, sin que sepamos si se llevó a cabo o no. Real Cédula para que el gobernador y cabildo informen de la mudanza del coro del iglesia catedral de Cartagena. J.P. Urueta, Documentos para la historia de Cartagena, p. 259.

${ }^{19}$ También hubo personas que debido a su condición noble pudieron hacer uso de sillas en el interior del templo. Por ejemplo, Francisco Álvarez de Castro, marqués de Bellestar, pretendió tener una silla dentro del coro. Concedida por el obispo el cabildo protestó al Consejo de Indias desde donde se mandó colocar la silla fuera del coro. Regidor de Cartagena, compró el título en 1758, en 1766 le fue concedido el título y pocos meses después hizo la solicitud de la silla, lo que da a entender el símbolo de estatus que ésta representa y la jerarquía social que reinaba en el interior de los templos. J.P. Urueta, Documentos para la historia de Cartagena, vol. III, p. 22.

${ }^{20}$ Jaime Valenzuela Márquez, Las liturgias del poder: celebraciones públicas y estrategias persuasivas en Chile colonial (1609-1709), Santiago, Chile, LOM, 2001, p. 236.

${ }^{21}$ Archivo General de la Nación (Bogotá, Colombia) (AGN) Sección Colonia (SC), Historia-eclesiástica (HE), 6, d.25, folios (ff.) 393r. y siguientes. El obispo Antonio María Cassiani, su altercado con el gobernador Jerónimo Badillo en la celebración del Corpus, por asuntos protocolarios de la catedral.
} 
El escándalo fue mayúsculo, por lo que se levantaron testimonios haciendo valer la costumbre que siempre se había usado de colocar una alfombra o cojín en todas las solemnidades en las que el Santísimo quedaba expuesto, sin que fuera estorbo para los prelados que de igual manera lo usaban. No sabemos si fray Antonio Cassiani desconocía esta costumbre usada en las iglesias americanas, pero su gobierno se caracteriza por enfrentamientos de todo calibre y contra todo aquello que él consideraba erosionar un aspecto de la jurisdicción eclesiástica. Los hechos son, sin embargo, muy sintomáticos del protocolo usado en las fiestas cuando entraba en juego la representatividad jerárquica.

Toda esta presencia corporativa en los ceremoniales religiosos tenía una enorme retribución simbólica para los participantes, especialmente civiles, que sancionaban con la cercanía a la divinidad la importancia del cargo, con todo el poder simbólico que tenía para el conjunto de la sociedad el contacto ritual con la divinidad. Por el contrario, el clero tenía asegurado ese contacto en virtud del ministerio sagrado que desempeñaba y que, dado el momento, se podía hacer uso para demostrar que era el canal entre la divinidad y el pueblo. Por ello podemos entender que obispo y gobernador se enzarzaran en una discusión que llegó hasta las manos, achacándose quién había ofendido a su Divina Majestad, tachando el obispo al gobernador de irrespetuoso y este proclamándose como humilde cristiano.

En 1731 se volvió a repetir una situación en la que el clero hizo suyo el control de la divinidad frente al vicepatrono. Después de la fiesta del Corpus, el gobernador protestó por la actuación del prelado al tapar el Santísimo al momento de entrar unas danzas a la catedral. El prelado intentaba poner orden y decoro en los templos de la ciudad y no veía nada edificante en unas danzas que congregaban multitud de gente expectante del baile. Evidentemente se pasaba rápidamente de la solemnidad de la celebración religiosa a un ambiente relajado de gran participación popular. No se veía correcto que durante el baile se volviera la espalda al Santísimo y se prestase, como era de esperar, más atención a la danza que a la ceremonia, lo que según el obispo convertía la catedral en "casa de diversión". La cubrición del Santísimo enojó al cabildo secular, más la decepción del pueblo congregado y del propio clero catedralicio que eran al mismo tiempo diputados de la fiesta. El enfado del gobernador fue mayúsculo, acusó al prelado de haber desairado a la ciudad, por lo que mandó 
que el cabildo secular saliese del templo, aunque disculpable por ser el primer año de su gobierno. A pesar de las intenciones del prelado por explicar su disposición, la disputa con el gobernador en el propio templo no se pudo evitar, derivando en el enfrentamiento entre ambos, algo cotidiano entre el obispo D. Gregorio Molleda y Clerque y el gobernador D. Antonio de Salas. El obispo acusaba al gobernador, quien le había respondido de mala forma, de entrometerse en asuntos puramente eclesiásticos con la excusa del patronato. El gobernador haría valer su puesto como vicepatrono y los derechos que tenía sobre asuntos eclesiásticos, hasta el punto de querer que se encerrase en la torre de la catedral -usada como cárcel eclesiástica- al maestro de ceremonias. La actitud del gobernador rebasaba con creces los límites del patronato hasta el punto de verse el obispo: “con las manos atadas para reformar lo que considera conveniente en servicio de Dios y reverencia de sus templos aún en esta materia privativa de la jurisdicción eclesiástica". ${ }^{22}$

No se nos escapa un cierto agobio por parte del prelado ante el peso del Real Patronato que en manos de vicepatronos muy celosos podía coartar la jurisdicción eclesiástica. Sin duda, el obispo pecó de novato al intentar reformar una costumbre local muy arraigada, y por lo que parece, sin contar ni siquiera con el parecer favorable de su clero. Fue tónica general este tipo de enfrentamientos; los prelados, acostumbrados a los tecnicismos teológicos y pureza del culto, entraban en confrontación con el clero al intentar reformar costumbres locales muy arraigadas. Al fin y al cabo los prelados no dejaban de ser elementos foráneos en unas diócesis, acostumbradas a cortos periodos de gobierno y a las sedes vacantes, donde no se admitían innovaciones y menos de recién llegados. Por su parte, los gobernadores se podían extralimitar en el ejercicio del Patronato disponiendo sobre cuestiones que estaban en la esfera jurisdiccional de la Iglesia, pero que la propia indefinición de los límites patronales inducía a sobrepasarlos. Las autoridades eclesiásticas no cuestionaron los principios del patronato pero no dejaron de mostrar su descontento cuando en virtud de sus principios se cuestionaban sus prerrogativas y más cuando se erosionaba su dignidad en actos públicos. ${ }^{23}$

\footnotetext{
${ }^{22}$ AGI, Santa Fe, 489, n.12. Disputa entre el gobernador D. Antonio de Salas el obispo D. Gregorio de Molleda y Clerque, Cartagena de Indias, 12 de julio de 1731.

${ }^{23}$ Los choques entre autoridades civiles y religiosas fueron endémicos en todos los territorios, contando con numerosos ejemplos de cualquier sede diocesana. Valga para el caso de Santafé los testimonios recogidos en Héctor Lara Romero, Fiestas y Juegos en el Reino de la Nueva Granada. Siglos XVI-XVIII, Bogotá, Universidad Distrital Francisco José de Caldas, Consejo Latinoamericano de Ciencias Sociales, 2015, p.121.
} 
La respuesta del fiscal fue favorable al mantenimiento de la tradición local de las danzas, argumentando que se celebraban en todas las diócesis sin que causaran escándalo, es más, en Cartagena se habían hecho hasta el momento sin protesta de anteriores prelados. La disputa la achacaba el fiscal a las tensas relaciones que existían entre obispo y gobernador, que se sumaba a una larga serie de desencuentros entre ambas autoridades. ${ }^{24}$

Los hechos llegaron a causar escándalo en la ciudad y rápidamente surgieron murmuraciones contra el obispo, acusándolo de llevar silla de manos tras el palio el día de la procesión, cosa incierta, pero que ante la cual el propio cabildo secular mandó hacer averiguaciones. Una situación caldeada que lejos de calmarse volvió a estallar al año siguiente.

Los planes del obispo no eran acabar con las danzas sino integrarlas en el cortejo y situarlas al principio de la procesión. Hasta el momento parece que habían formado parte del cortejo pero sin ocupar un espacio concreto, integradas entre los restantes miembros, pues se indica que no deben ir entre los religiosos ni entrar en la catedral. Aunque parece que en Cartagena, a pesar de los intentos de los prelados, la procesión y ceremonia siempre se hizo con cierto aire festivo y menor solemnidad de lo que hubieran deseado ciertos prelados. No obstante, el obispo Molleda no cejó en su empeño de reformar estas actitudes y en la celebración del Corpus de 1732 no dejó entrar a los diablillos en la catedral ni que se ejecutaran unas danzas de pastorcillos frente al Santísimo. En consecuencia, el cabildo protestó con los argumentos anteriormente usados, remitiéndose a la honda tradición de las danzas en los distintos dominios españoles. En este caso el obispo llegó a más, pues no se contentó con cubrir la custodia sino que la retiró del presbiterio junto con toda la clerecía. El cabildo secular abandonó también el templo junto con parte del público asistente. ${ }^{25} \mathrm{~A}$ pesar de la insistencia del cabildo de no existir nada irreverente en las danzas, bien la obstinación del prelado o bien algún comportamiento observado fue lo que llevó a su retirada, no la prohibición de la danza, compromiso al que había llegado. De esta manera, el obispo se apuntaría una victoria frente al gobernador demostrando el papel de la Iglesia, la única que

\footnotetext{
${ }^{24}$ Ibídem, Respuesta del fiscal. Consejo 9 de junio de 1732.

${ }^{25}$ AGI, Santa Fe, 489, n.16. El cabildo secular al rey. Cartagena de Indias, 14 de junio de 1732.
} 
podía intervenir en cuestiones de culto. Incluso demostraba que era la única institución garante de la presencia de Dios entre el pueblo, la retirada del Santísimo y no su cubrición era una claro mensaje ante las autoridades civiles. Una idea que ya había demostrado meses antes al mandar que las llaves de los sagrarios donde se reservaban las formas el Jueves Santo no fueran custodiadas por el gobernador, costumbre en los dominios hispánicos, sino que lo hicieran los propios curas. ${ }^{26}$

No sabemos lo que ocurrió al año siguiente, pero en octubre de 1733 el obispo recibió una Real Cédula de cuatro de julio de 1732 por la que se ordenaba que no impidiese las danzas al no encontrar irreverencia. El obispo respondió que, en acuerdo con el gobernador, había quitado lo más irreverente de la danza para que pudiese celebrarse sin inconvenientes. ${ }^{27}$

En los testimonios de los que disponemos sobre la celebración del Corpus, encontramos que los obispos ponían empeño en reformar una celebración que en su opinión tendía demasiado a lo festivo y mostraba poco boato y devoción. Al contrario de lo que podemos observar en lo referentes a otras diócesis, más aún en las capitales virreinales, el Corpus de Cartagena no destacaba por la solemnidad de la procesión ni por una estricta reglamentación. Al contrario, los participantes, tanto clérigos como seglares, destacan por una gran relajación en una fiesta que debía mostrar todo lo contario. Al mismo tiempo, es también sintomático que sea la autoridad eclesiástica la que se encargue de su reglamentación. Mientras que las autoridades locales estaban más atentas a los aspectos festivos que a cuestiones de representatividad, en las que ellos eran una parte destacada, lo que lleva a relativizar las ordenanzas tan rígidas que desde la Corona se establecían para su representación.

Un ejemplo más en este sentido es el papel que jugaba el clero, que como hemos visto anteriormente tampoco era muy celoso del orden. En 1763 el obispo Manuel de Sosa Betancour se propuso como sus antecesores dotar de mayor esplendor y devoción el culto al

\footnotetext{
${ }^{26}$ AGI, Santa Fe, 489, n. 19. Carta del obispo Gregorio Molleda y Clerque al rey. Cartagena de Indias, 20 de abril de 1732.

${ }^{27}$ Hay que destacar que las autoridades religiosas siempre tuvieron sus reparos en los aspectos festivos de la celebración al considerarlos que robaban protagonismo al elementos religioso. Ya en el siglo XVI encontramos referencias contra estos elementos de este tenor en las disposiciones del obispo Zumárraga en México. En N. Sigaut, "Corpus Christi: la construcción simbólica de la ciudad de México", p. 48.
} 
Santísimo Sacramento. La hermandad sacramental, dedicada a ello, estaba muy decaída por lo que intentó relanzarla animando a que se inscribieran en ella personas notables de la ciudad. Con ello, la cofradía vivió una revitalización aumentando de esta manera el número de hermanos y por tanto el patrimonio de la cofradía con nuevas alhajas y reparos en la capilla. De igual manera se intentó dotar de mayor solemnidad cualquier salida del Santísimo en la que era acompañado por cualquier tipo de personas de "inferior posición". ${ }^{28}$ No obstante, la reforma de la hermandad había comenzado un poco antes en 1758 cuando el celador de la cofradía, D. José de la Bárcena Respuela quien sería regidor perpetuo de la ciudad, ${ }^{29}$ decidió que los hermanos acompañasen al santísimo con velas dado el poco lucimiento de la procesión del Corpus. Al mismo tiempo reclamaba que se obligase a los hermanos a llevar un distintivo externo de pertenencia a la cofradía, en concreto una medalla que les diferenciaría del resto de participantes en la procesión, con lo que se confería a los hermanos un distintivo social de diferenciación. ${ }^{30}$ No obstante, parece que este tipo de distintivos no era de suma importancia para los hermanos de la cofradía, puesto que hubo que obligar a llevarlos. Además, se infiere que entre las filas de hermanos iban mezclados otros que no lo eran. La medida no llegó a calar del todo entre los hermanos según lo que aportaba el obispo años después. La hermandad, que debería ser señera en la ciudad, por congregar a la élite local, no estaba muy interesada en hacer notar su diferenciación social, incluso hasta el punto de permitir que personas de más baja condición fueran mezclados con ellos. Si bien en aspectos económicos sí estuvo muy comprometida, la reforma de la capilla sacramental pudo hacerse en esta época, las cuestiones de representatividad no eran tomadas con gran interés. Incluso aspectos protocolarios definitorios de la procesión del Corpus y del mensaje simbólico con que se quiso revestir pasaban por la gentes de la ciudad sin levantar grandes preocupaciones. La propia cofradía solicitó al obispo un cambio en el orden del cortejo del Corpus al solicitar que fueran los hermanos de la sacramental los que precedieran al palio con la custodia, portando cirios o faroles, debido al poco lucimiento de la procesión. Era el lugar de máxima representatividad e importancia ceremonial pues se encontraba justo

\footnotetext{
${ }^{28}$ AGI, Santa Fe, 1034, n. 15. Carta del obispo Manuel de Sosa Betancour al rey. Cartagena, 6 de junio de 1763.

${ }^{29}$ José de la Bárcena Respuela era originario de España, había nacido en Prezanes (Santander), donde también fue regidor del cabildo. Pasó a Cartagena donde se casó con Dña. Ana María Barragán, natural de la ciudad. Archivo Histórico Nacional (Madrid, España), Estado-Carlos III, exp. 720. Expediente de pruebas del caballero de la orden de Carlos III, José Vicente de la Bárcena y Barragán Respuela y Cortés de Mesa, 1793.

${ }^{30}$ AGI, Santa Fe, 1034, n. 15. Petición de José de la Barcena Respuela.
} 
delante de la divinidad, posición que hasta el momento habían ocupado los religiosos de santo Domingo por su antigüedad. La hermandad intenta justificar el cambio aduciendo a que eran los únicos que alumbraban al Santísimo, por tanto, hacen hincapié en que no era una preferencia a sus personas sino al oficio de alumbrar al mismo Dios. Tanta preocupación en justificar esta medida indica de manera indirecta la importancia en el orden de la procesión y la sensibilidad que al respecto podía causar cualquier modificación. Las precauciones de los hermanos no eran infundadas pues no se pudo evitar que el conflicto estallase en tan delicado tema de representación jerárquica, donde la mayor importancia venía marcada por la proximidad a la custodia. Así pues en la procesión de 1763 tras salir de la catedral y llegar a la plaza de Santo Domingo, los religiosos dominicos decidieron regresar a su convento dolidos por un supuesto agravio al ser desposeídos de su posición privilegiada. No obstante, el prelado, que había accedido a la petición de la cofradía Sacramental en 1759, no entiende la actitud de los dominicos quienes hasta la fecha no habían hecho oposición. Muy inteligentemente y para evitar escándalos mayores el obispo no recriminó a los dominicos su actitud y decidió ponerlo en conocimiento de las autoridades competentes.

A pesar de lo que se pueda pensar, el supuesto agravio no lo fue tal para los religiosos del convento cartagenero, quienes el día después se presentaron en la casa episcopal para disculparse. Achacaban el escándalo a la actitud del vicario provincial fray Braulio de Herrera quien había convencido a los religiosos más jóvenes para que actuaran de tal forma. Tanto religiosos como obispo hacían referencia al vicario por sus "lastimosas distracciones" sin que sepamos exactamente a qué se refieren. En cualquier caso el origen de la disputa no fue por cuestiones de jerarquía en el orden de la procesión, sino que detrás debía existir algún interés por polemizar con el obispo, lo cual fue una estrategia que no resultó al no entrar éste en censuras. La repuesta del fiscal, fue en este sentido, dando gracias al obispo por su actitud y cursando una orden para que interviniera el general de Santo Domingo e investigara las actuaciones del vicario. Por lo que respectaba al orden de la procesión, confirmó la disposición del prelado que seguía el ceremonial romano, pues el cambio no fue concedido a los cofrades en sí, cuyo rango era inferior a los religiosos, sino por la actividad que desempeñaban en la procesión que era la de alumbrar al Santísimo. A ellos debían precederles 
las órdenes religiosas y a estas el resto de comunidades de seglares que no alumbraban al Santísimo. ${ }^{31}$

Unas actuaciones en este Corpus de mediados de siglo en el que permanece cierta relajación de los participantes en la fiesta. A pesar de los intentos de prelados anteriores y de la propia cofradía, el cortejo no resplandecía como debía hacerlo para tan solemne festividad. La hermandad sacramental a pesar de congregar a personas de sonada posición brilló por el decoro de la capilla pero no por un elitismo que tuviera su exteriorización en un cortejo urbano, concebido para mostrar y dejarse mostrar. Cuestiones de protocolo que en otros contextos hubieran destapado sonados conflictos, no pasaron de una tibia respuesta, como la sustitución de los religiosos cerca del palio.

La festividad del Corpus continuó solo con pequeñas modificaciones que se debían al parecer particular de alguna autoridad. Por ejemplo el empeño del gobernador D. José de Sobremonte porque los soldados que acompañaban las salidas del viático o en la propia procesión del Corpus fueran en los costados y no detrás como siempre se había llevado a cabo. El acompañamiento militar era otro de los elementos característicos del cortejo, solían ser dos o cuatro soldados del cuerpo de guardia, llevaban las armas terciadas con la bayoneta puesta y quitado el sombrero. La propuesta del gobernador contó con la oposición del clero, pues se produjo durante una salida del viático, y del propio obispo que no dudó en reclamar al Consejo de Indias. Se puede comprobar cómo la defensa de lo que se consideraba la tradición local era tajante y difícilmente se modificaba. La respuesta del fiscal al gobernador constituye un buen ejemplo del concepto de representatividad que suponía la esencia de la fiesta. Recordaba que la participación de soldados no era una cuestión para defender al Santísimo contra un posible ultraje, como argumentaba el gobernador, difícil que ocurriese en un territorio católico. Incluso indica que es injurioso a la nación el pretender que el Santísimo llevara guardia para su protección, pues no se podía entender que nadie fuera a atacarlo, cosa que ni siquiera se realizaba cuando se permitía la existencia de gentes de otras religiones (judíos y moriscos), el mero hecho de plantearlo ofendía a los súbditos españoles.

${ }^{31}$ AGI, Santa Fe, 1034, n. 15. Respuesta del fiscal, 28 de marzo de 1764. 
Bien al contrario el acompañamiento era por acatamiento y reverencia, por lo que daba igual donde se colocasen. Según el fiscal, las leyes de Castilla nunca regularon la presencia de soldados como tales, sino que todos acudían como fieles cristianos, y en este caso, portaban las armas como símbolo de su oficio militar. Termina con una aclaración referente a no hacer novedades por los problemas que conllevaban cuando solo respondía a apetencias personales y sin consenso "cuando se sabe el mucho poder que tiene en estas materias la práctica de cada país y el pulso y madurez que se debe proceder en introducir novedades". 32

En todas las disposiciones hay un intento de dotar de mayor orden jerárquico y boato a la procesión del Corpus, haciendo referencia a la forma de ejecutarlo en otras sedes diocesanas. No obstante, en todas las disposiciones aflora una cierta relajación y desidia por parte de los participantes en los que se puede vislumbrar una falta de interés en las cuestiones protocolarias de representatividad. Un interés que surge con fuerza cuando se siente tocada la costumbre del lugar, pues cualquier modificación se entiende como un ataque a la ciudad. Puesto que no hubo festividad que presentase mejor el pulso de la ciudad, la participación de todos los elementos sociales hacía que surgiera un espíritu urbano al que se remitiría cuando se sintiera que la fiesta, como imagen de la ciudad, no fuera respetada.

\section{Los aspectos festivos}

La festividad del Corpus no se podía entender sin tener en cuenta los elementos populares que amenizaban la fiesta y servían tanto de divertimento para el pueblo como un medio visual de significar elementos doctrinales. Se trataba de danzas, bailes y representaciones con un sentido teológico en las que participaban gentes disfrazadas. Su inclusión en el Corpus consta desde los orígenes de la fiesta y fueron reguladas para evitar que los elementos profanos sobrepasaran a los religiosos. En América estas danzas conllevaron la inclusión de elementos indígenas, en las que participaban de manera directa,

\footnotetext{
${ }^{32}$ AGI, Santa Fe, 1034, n. 12, fol. 9v. Protocolo sobre la salida del Santísimo. Respuesta del fiscal, Madrid 12 de marzo de 1764.
} 
dada la complejidad del misterio que se exaltaba, la transubstanciación, permitió la incorporación de elementos prehispánicos lo que le aseguró su fácil implantación. ${ }^{33}$

Por otro lado, estas danzas sirvieron para integrar dentro del modelo político-religioso colonial a los grupos no hispanocriollos como indios, negros o castas, ${ }^{34}$ una práctica heredera de la península donde también participaban grupos étnicos como los gitanos. ${ }^{35} \mathrm{La}$ participación de los grupos étnicos suponía su integración en el orden colonial al permitir unas formas culturales propias pero sometidas y amoldadas a la cultura oficial hispana a cuyas formas estaban amoldadas. ${ }^{36}$

Siguiendo la tradición medieval la festividad se había llenado de elementos profanos recogidos de tradiciones anteriores que acompañaban tanto a la procesión como formando parte de otros momentos de la festividad. En Cartagena hay constancia de su existencia y reglamentación, sin embargo, no se hace referencia a la identificación de estos bailes con ningún grupo social concreto, lo cual no quiere decir que no la tuviera, pero hasta el momento solo podemos suponerlo. La omisión puede deberse a que no tuviera un marcado carácter racial, la escasa presencia de indígenas en la ciudad hace pensar más en la presencia de mulatos o negros, grupos con mayor representación en la población. Sin embargo, la documentación de la que se ha dispuesto nada alude a un origen racial concreto sino a la reglamentación de unos bailes cargados de una simbología propia de la mentalidad medieval europea, aunque en su puesta en escena (trajes, coreografías, etc.) pudiera mantener

\footnotetext{
${ }^{33}$ Antoinette Moliné "Las dos caras de una custodia: una invención andina del Corpus Christi”, en Gerardo Fernández Juárez y Fernando Martínez Gil (coord.), La fiesta del Corpus Christi, Cuenca (España), Universidad de Castilla-La Mancha, 2002, p. 349.

${ }^{34}$ Existen ejemplos de esta participación para las principales ciudades coloniales, debido a la conservación de actas capitulares donde se regulaba la festividad. Varios ejemplos los podemos encontrar en: J. Valenzuela Márquez, Las liturgias del poder: celebraciones públicas y estrategias persuasivas en Chile colonial (16091709), p. 149; L. Curcio-Nagy, "Giants and Gypsies: Corpus Christi in Colonial México City”, pp. 1-27; Juan

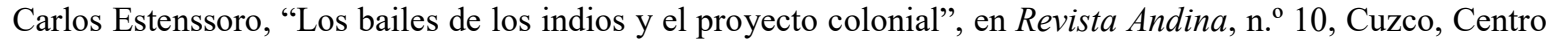
Bartolomé de las Casas, 1992, pp. 353-404.

${ }^{35}$ Fernando Jiménez Carpio, Fernando, "Las danzas gitanas en el Corpus Christi entre los siglos XVI y XVII”, en Amarí. Revista Cultural Gitana, n. ${ }^{\circ}$ 7, 2017; M. López Martínez, “ Gitanos y corpus Christi en Jaén en la primera mitad del siglo XVII" Boletín del Instituto de Estudios Gienneses, 176, Jaén, 2000, pp. 737-750. Begoña Consuegra Cano, "La danza de la Judiada del Corpus de Camuñas (Toledo)", en G. Fernández Juárez y F. Martínez Gil (coord.), La fiesta del Corpus Christi p. 425-462.

${ }^{36}$ J. Valenzuela Márquez, Las liturgias del poder: celebraciones públicas y estrategias persuasivas en Chile colonial (1609-1709), p. 152.
} 
reminiscencias africanas o indígenas. Aun así, a diferencia de otros lugares con una carga indígena más fuerte (Perú o Nueva España) la omisión de referencias raciales nos indica que este elemento no era el fundamental en la representación de la danza, sino más bien lo que levantó más suspicacias era el contenido de ella. En consecuencia, todo indica que los participantes no lo hacían en virtud de una representación como grupo social, sino como meros actores. En todo caso es muy probable que la participación de estos grupos quedara circunscrita a esta tipo de danzas, a través de las cuales se les permitía una recuperación de las formas propias pero dentro de los parámetros de la cultura dominante. Su situación, al principio de la procesión, las revestía de un fuerte carácter metafórico característico de la fiesta en la que se simbolizaba la victoria del bien contra el mal. Común en otros lugares servía para mostrar la posición subordinada frente a la cultura dominante. ${ }^{37}$

Estas representaciones tenían lugar a lo largo de los días de la festividad. El rezo de las Vísperas terminaba con una exposición del Santísimo en el interior del templo; al término de la exposición, todavía con la custodia expuesta, entraban en el templo unos diablillos y muchachos, practicando una danza frente al altar donde se postraban; al momento salía un ángel que mediante unos versos les reprendía con lo que salían corriendo del templo. El significado simbólico que sustentaba esta actuación dentro del templo era claro y se repetía en otras ciudades del mundo hispánico con formas similares. La presencia del mal, en este caso representado por unos diablillos, es vencido por el propio Cristo resucitado presente en la Eucaristía al ser espantado por un ángel; se trata del triunfo del bien sobre el mal, tema muy recurrente en la cosmovisión católica que acompañaba a la fiesta. ${ }^{38}$ No sabemos exactamente cuál era el atuendo ni cómo eran las danzas, pero debía asemejarse a unos diablos y figuras extrañas, que significarían el mal frente a otros asimilados a ángeles. Este tipo de danzas nombradas como matachines o mojarillas, diablillos en el caso cartagenero, fueron muy comunes en todas las procesiones de Corpus y daban una nota festiva que contrastaba con el boato de la celebración. ${ }^{39} \mathrm{~A}$ pesar de la brevedad de la descripción y de

\footnotetext{
${ }^{37}$ Carolyne Dean, Inka Bodies and the Body of Christ. Corpus Christi in Colonial Cuzco, Peru, Durham, Duke University Press, 1999, p. 53.

${ }_{38}$ Para la representación del diablo en fiestas ver Jairo Henrique Soto Hernández, El Diablo en la Cultura Popular del Caribe Colombiano. Del Corpus Christi al Carnaval de Barranquilla, Barranquilla, Editorial La Iguana Ciega, 2012.

${ }^{39}$ Con el nombre de mojarrillas se conocieron en Andalucía, niños disfrazados de diablos que golpeaban con
} 
posteriores alusiones no se ve en ella ningún rasgo que haga referencia a un grupo étnico concreto, la trasplantación de la cultura cristiana es clara, usando unas formas estandarizadas para todo el mundo hispano.

Las referencias que encontramos al respecto siempre hacen alusión a los aspectos lúdicos que despertaban. De ahí que el regocijo que acompaña este tipo de representaciones no fuera bien visto por la actitud, demasiado purista, de muchos prelados que veían más irreverencias que mensaje teológico en lo representado. Como se ha hecho referencia anteriormente el obispo limeño D. Gregorio de Molleda y Clerque limitaría este tipo de representaciones, lo que supuso el enfrentamiento con su clero y gobierno civil quienes mantenían el apoyo a la tradición local. ${ }^{40}$

Las celebraciones del Corpus continuaron en la ciudad, aunque no sabemos si con las modificaciones del obispo Molleda, o tras su gobierno volvieron las danzas al interior del templo. Podemos pensar que el ambiente en el interior del templo no era el más adecuado provocando gran escándalo ante las danzas. El posicionamiento de las autoridades locales a favor de mantener la tradición y los aspectos lúdicos de la fiesta hay que enmarcarlos en un contexto de escaparate social.

Hay que tener en cuenta que a todo este tipo de festividades acudían gentes no solo de la ciudad sino también del entorno más inmediato, barrios periféricos y zonas rurales adyacentes. El ambiente festivo debía ser predominante constituyendo al mismo tiempo una oportunidad de escaparate pero también de problemas. Atraídos por el ambiente festivo y la fastuosidad del ritual, las autoridades locales y élites sociales aprovechaban para hacer

vejigas al público que encontraban a su paso. Salvador Rodríguez-Becerra, "El Corpus en Andalucía. De fiesta de poder a fiesta de la identidad", en G. Fernández Juárez y F. Martínez Gil (coord.), La fiesta del Corpus Christi, p. 387. De igual modo existieron en gran parte del antiguo virreinato de la Nueva Granada estas danzas, que aún conservan muchas localidades pero vinculadas con el carnaval. Ver Marcos González Pérez (comp.), Fiesta y región en Colombia, Bogotá, Coop. Editorial Magisterio, 1998. La celebración del Corpus en Caracas durante el siglo XVII contó con tarasca, gigantes y diablitos, estos últimos eran interpretados por personas negras que portaban máscaras, ver Carlos F. Duarte, "Las fiestas del Corpus Christi en la Caracas Hispánica (tarasca, gigantes y diablitos)", Archivo español de arte, 64, n. ${ }^{\circ}$ 255, 1991, p. 340.

${ }^{40}$ En otros lugares tampoco gustaron este tipo de danzas, por ejemplo el obispo de Caracas Diego de Baños y Sotomayor también las limitó en 1687, aunque en este caso llevaban un marcado carácter étnico al denominarse danzas de mulatas, negras e indias. Ver C. F. Duarte, "Las fiestas del Corpus Christi en la Caracas Hispánica (tarasca, gigantes y diablitos)", p. 341. 
ostentación de su poder y riqueza ante una masa popular predispuesta a recibir el mensaje que persuasivamente se ofrecía a través de imágenes y palabras. ${ }^{41}$ Los regidores de la ciudad actuaban como diputados de la fiesta por lo que contribuían a su mantenimiento y lucimiento, la decoración de la ciudad, su limpieza y la grandeza de los aspectos no religiosos corría de parte de la municipalidad con lo que se reforzaban los aspectos de prestigio social. La ciudad mostraba sus mejores galas demostrando en el área circundante su poder político. Al fin y al cabo el mantenimiento de los aspectos festivos era una manera de reforzar el papel dirigente del patriciado urbano y de mostrar la riqueza de la ciudad frente a los foráneos.

Frente a esta visión, se posicionan obispos cuya formación estaba muy alejada de la cultura popular, y más en un tiempo ya cercano a los nuevos aires reformistas ilustrados. Con el tiempo terminarían por calar entre las élites políticas con lo que se iría borrando toda manifestación popular de la celebración.

Todo apunta a que las danzas continuaron a lo largo de toda la centuria, aunque el decaimiento de la fiesta comenzó a hacerse notar en la segunda mitad de la centuria.

En mayo de 1776 el deán de la Catedral, Manuel Moyano y Maceda hizo llegar a los diputados de la fiesta del Corpus -los regidores Bartolomé Jiménez Morquecho y Manuel José de Vega- una sentida carta por que el cabildo eclesiástico recriminaba la negativa de la ciudad a pagar la cera que se utilizaba en la procesión. El deán advertía que los miembros del cabildo debían participar económicamente al mantenimiento de la fiesta como signo de honor de la ciudad, de su celo cristiano y ejemplo para la población, además de ser un símbolo del lustre del ayuntamiento. Por otro lado, su actitud podía servir de precedente para bajar las ayudas y mantenimiento de otras fiestas que se celebraban en la catedral. El año anterior ya se había procedido de la misma manera, aceptándolo el cabildo por encontrarse la ciudad en una difícil situación económica. ${ }^{42}$ En consecuencia, repercutió en el deslucimiento de las celebraciones.

\footnotetext{
${ }^{41}$ J. Valenzuela Márquez, Las liturgias del poder: celebraciones públicas y estrategias persuasivas en Chile colonial (1609-1709), p. 216.

42 El cabildo de la ciudad contribuía económicamente al mantenimiento de las fiestas que se celebraban en la ciudad, las consideradas de tabla. Circunstancias desfavorables para ciudad hacían que las aportaciones bajaran.
} 
Son muy interesantes las continuas apelaciones al orgullo cívico que suponía el fasto y solemnidad de una fiesta, cuyo boato demostraba la grandeza de la ciudad. Al mismo tiempo, hacen referencia a su orgullo de cartageneros, de pertenecer a una ciudad cuyo ayuntamiento estaba compuesto por gente noble. Una nobleza que debía tener su reflejo en el gasto y la ostentación de los preparativos festivos. A pesar de que en las palabras de los prebendados es imposible no ver una adulación conducente a obtener lo que solicitaban, muestran hasta qué punto dotar de solemnidad una fiesta era símbolo del estatus, no solo del que participaba económicamente en el decoro, sino de la propia ciudad. La festividad, no solo se mostraba como un escaparate donde las élites podían mostrar su estatus social, sino que era todo un mensaje para mostrar la posición política y económica de Cartagena. En este sentido, no podemos dejar de ver un intento de emulación de las ciudades periféricas respecto a las capitales virreinales. Recepciones de gobernadores y obispos pretendía emular las correspondientes de virreyes y arzobispos, el resto de festividades también buscarían una emulación que al replicar modelos virreinales, e incluso peninsulares, las acercasen simbólicamente a lo que estas ciudades representaban en el plano político. ${ }^{43}$ Precisamente en un momento en el que los virreyes comenzaron a pasar largos periodos de tiempo en la ciudad, escenario de las tomas de posición de varios de ellos.

Sin embargo, las limitaciones económicas de la ciudad se hacían sentir y tenían su consecuencia directa en la reducción del presupuesto para festejos. Por tanto, el año anterior a la queja del cabildo, la festividad del Corpus había perdido los sermones y la música -que se realizaban en el interior del templo durante las ceremonias religiosas- además se habían tenido que suprimir las danzas "con que se hermoseaban y se estimulaban los júbilos de los fieles su agradecimiento y reconocimiento al soberano señor por tan alto beneficio" ${ }^{44}$ Por tanto, habría que dar la razón al cabildo cuando refería el deslucimiento de la celebración,

Por ejemplo, en 1665 cuando un temporal arrasó parte de la muralla, el cabildo pretendió reducir su contribución a las fiestas celebradas en la catedral a lo que aportaban el resto de cofradías y en caso de que no se aceptase, trasladar la celebración a otro templo. Asunto descartado por parte del consejo. J.P. Urueta, Documentos para la historia de Cartagena, doc. 504, p. 105.

${ }^{43}$ J. Valenzuela Márquez, Las liturgias del poder: celebraciones públicas y estrategias persuasivas en Chile colonial (1609-1709), p. 25.

${ }^{44}$ AGN, SC, HE, 14, d. 2, f. 120v. Carta del cabildo eclesiástico al cabildo de la ciudad. Cartagena, 30 de mayo de 1776 . 
donde se había reducido todo ambiente festivo, incluso el culto habría perdido parte de su solemnidad.

Por otro lado, los miembros del cabildo no pudieron contener su disgusto con el ayuntamiento, y terminaron por recriminarles el excesivo gasto de la construcción de las nuevas casas capitulares, recordando que para el éxito temporal era importantísimo el culto al Santísimo. Por tanto, reclamaban que todas las fiestas de la ciudad recobrasen los lucimientos perdidos en honor del mismo ayuntamiento "buen ejemplo del pueblo, desempeño de la Real confianza de Nuestro muy Católico rey y señor y gloria del omnipotente". 45

No obstante, a pesar de todo lo argumentado, el cabildo secular no estaba dispuesto a contribuir más al mantenimiento de la fiesta. El deán había rescatado muy acertadamente toda la teoría respecto al significado simbólico de la fiesta y el papel que en ella representaban las autoridades civiles. Pero para estas había otras necesidades más urgentes que toda una teoría que, sin llegar a negarla, chocaba frontalmente con una realidad mucho más prosaica pero más acuciante. Recordaban que la colaboración en la cera exigida no era una obligación y se realizaba de forma voluntaria. Como solución proponen la entrega de las velas al clero pero estas debían ser devueltas tras el término de la procesión, puesto que estos se la quedaban para uso propio y en algunos casos ni siquiera acudían a la procesión con ella. El cabildo era quien sostenía económicamente la fiesta aunque había recortado su participación siguiendo las directrices del Virrey. ${ }^{46}$ Aun así, ese año había colaborado con 51 pesos para música, armar el palio, la cera del altar, mientras que los diputados de la fiesta habían hecho lo propio con otros 300 pesos de los 500 que había aportado otros años y se aseguraba la cera para la procesión. La situación en la ciudad era difícil por lo que se había reducido todo lo accesorio de la fiesta, con lo que se habían obviado las danzas, a la espera de mejores años en los que se pudiera volver a la situación anterior. Eso sí, no terminaron su exposición sin recordar al cabildo eclesiástico que la reparación de las casas capitulares era una cuestión

\footnotetext{
${ }^{45}$ AGN, SC, HE, 14, d. 2, f. 122r.

${ }^{46} \mathrm{Al}$ momento era virrey Manuel Antonio de Flórez, quien había permanecido en la ciudad hasta marzo de ese mismo año. Eduardo Lemaitre, Historia General de Cartagena, vol. II, Bogotá, Banco de la República, 1983, p. 362 .
} 
que no les competía y devolvían la recriminación al recordar que el clero solo participaba con su presencia, en un claro mensaje para mostrar quien sufragaba la festividad. Una situación que el cabildo catedral tiene que aceptar debido a la cercanía de la fiesta y las consecuencias que sobre la población podía generar su deslucimiento. A pesar de que la fiesta no se celebrase con el mismo boato que años precedentes debía seguir siendo una de las festividades más destacadas de la ciudad.

Finalmente se llegó al acuerdo de repartir solo la cera para la procesión y fuera devuelta tras su término. Asimismo se dispuso por parte del cabildo eclesiástico y los diputados de la fiesta que las danzas fueran mejor "armadas" (podemos entenderlo como mejor preparadas) que en años anteriores. ${ }^{47}$ Aun así, el cabildo solicitó una repuesta de la Audiencia para que asegurase la no obligatoriedad de la donación de cera. La respuesta de la Audiencia fue en la línea de lo planteado por el ayuntamiento, recordando que los gastos relativos al culto, partían de la propia Iglesia y del cabildo en lo referente al ornato público, el cual debía ayudar por su parte a "acreditar su fervor, devoción y celo, con ejemplo público sin detrimento de las rentas", como se hacía en Santafé. ${ }^{48}$ Todo indica que se puso fin a una tradición de colaboración en el mantenimiento de la fiesta que la Iglesia quiso convertir en ley, cuestión no aceptada por el cabildo ni la Audiencia. La colaboración del ayuntamiento en la organización de todos los aspectos de la fiesta había sido necesaria para que esta estuviera revestida de cierto boato. En cierto sentido, se entiende si tenemos en cuenta la relativa cortedad de las rentas eclesiásticas, que difícilmente podían sufragar todo el aparato ceremonial de una solemnidad como la del Corpus. Un ejemplo era el de la propia capilla musical de la catedral, cuyos músicos recibían 25 pesos de los diputados de la fiesta por su asistencia a las Vísperas, a la misa de la festividad, a la octava y su actuación en las cuatro estaciones que se rezaban durante el recorrido. El mantenimiento de la capilla peligraba con la medida dictada por la Audiencia, pues cobraban por trabajo realizado costeándose cada

\footnotetext{
${ }^{47}$ AGN, SC, HE, 14, d. 2, f. 138v. Carta del cabildo eclesiástico al cabildo de la ciudad. Cartagena, 30 de mayo de 1776.

${ }^{48}$ AGN, SC, HE, 14, d. 2, f. 141r. Respuesta de la Audiencia de Santafé, 2 septiembre de 1777.
} 
uno su instrumento. Sin embargo, la Audiencia se remitió a lo anteriormente dictaminado al considerar que pertenecía a la Iglesia su mantenimiento. ${ }^{49}$

La festividad del Corpus llegaba a finales del siglo XVIII deslucida por la reducción del presupuesto destinado a solemnizarla. ${ }^{50}$ Pero el principal problema que se cernía sobre la festividad era los nuevos aires ilustrados y reformistas de Carlos III por los que se iba a despojar a la fiesta de todo contenido popular en el intento de buscar una religión más racionalizada y purista. Para ello se reforzaron los aspectos más litúrgicos y teológicos dotando de más presencia clerical a la festividad, al encontrar las manifestaciones populares como elementos de una religión basada en supersticiones que respondían a la ignorancia del pueblo. En 1777 se determinó la prohibición de bailes en las iglesias y delante de imágenes, en 1780 le tocaría el turno a las tarascas, gigantes y demás elementos de contenido más profano, ${ }^{51}$ aunque no fue fácil su cumplimiento dada su popularidad. ${ }^{52}$

\section{Conclusión}

Las celebraciones litúrgicas, como cualquier acto en el que participaban las instituciones de gobierno, constituían un buen espejo donde quedaba reflejada la sociedad colonial y toda la jerarquía política e institucional del sistema colonial. La ciudad de Cartagena no fue ajena a todo este ceremonial festivo que se desplegaba a lo largo del año, como una catequesis tanto civil como teológica, que a través de las persuasivas formas barrocas hacían entender los principios sobre los que se asentaba la sociedad hispánica. La festividad del Corpus fue el mejor medio de hacer traslucir el mensaje y su celebración fue

\footnotetext{
${ }^{49}$ AGN, SC, HE, 14, d. 2, f. 141r. Petición de Juan Antonio de Herrera a la R. Audiencia de Santa Fe.

${ }^{50}$ Semejantes testimonios encontramos en otras poblaciones de la Nueva Granada, como en Popayán donde en 1785 el presbítero de la cofradía del Santísimo Sacramento se refería en los mismos términos de decadencia de la fiesta. H. Lara Romero, Fiestas y Juegos en el Reino de la Nueva Granada. Siglos XVI-XVIII, p. 124.

51 Víctor Mínguez, Inmaculada Rodríguez Moya, Pablo González Tornel,Juan Chiva, La fiesta Barroca. Los Virreinatos Americanos. (1560-1808), Castellón de la Plana, Universitat Jaume I y Universidad de las Palmas de Gran Canaria, 2012, p.134.

${ }^{52}$ Incluso con los gobiernos republicanos se mantuvo este tipo de representación en las mismas líneas que en la época colonial como demuestran las descripciones de la procesión en Bogotá. Ver José María Cordovez Moure, Reminiscencias de Santafé y Bogotá, Bogotá, Fundación editorial Epígrafe, 2006, pp. 78-79. Hoy en día muchos de los elementos han pasado a formar parte de las fiestas de carnaval.
} 
cuidada y reglamentada por la Corona con la gravedad que le correspondía. En las capitales virreinales y aquellas ciudades de mayor poder simbólico, la fiesta llegó a una gran complejidad ceremonial y simbólica. En las ciudades periféricas o con menor grado de representatividad política, se replicó el mismo modelo, adaptándolo a las circunstancias locales. Para las autoridades, especialmente en Cartagena sus prelados, se intentó emular lo que ocurría en los centros políticos de referencia o en las ciudades españolas, de ahí los intentos por reformar unas costumbres que se asentaban en unos principios sociales difíciles de mover.

En este sentido, la celebración del Corpus en Cartagena destacó por unos elementos festivos que sobresalían por encima de las estrictas normas organizativas que nos muestra la reglamentación oficial. Sin una población indígena importante, con una destacada población esclava y afrodescendiente, las representaciones festivas no tuvieron un carácter étnico como el que podemos encontrar en manifestaciones del Corpus en Perú o México, pero debieron ser herederas de una cultura despojada y reinventada bajo formas europeas, solo así pudo concitar el aplauso y la identificación de la mayor parte de la población. El apoyo del clero local y de las autoridades civiles hacia estas manifestaciones demuestra la aparición de unas formas culturales que, sin bien era híbridas, eran los suficientemente asépticas como para que se sintieran identificados amplios sectores sociales.

A pesar de la reglamentación del orden y del conocimiento que su significado implicaba, la práctica fue mucho más relajada. A pesar de que fuera inflexible en algunos aspectos, así lo vemos en cuestiones de preeminencias entre jurisdicciones, civil y eclesiástica, lo fue tanto en cuestiones sociales. En una sociedad fuertemente jerarquizada es difícil explicar actitudes como las que relatan los informes expuestos en los que gente de menor condición fueran mezcladas con otras de mayor, formando parte de un mismo cortejo. Aunque fueran personas de grupos sociales similares, esta “dejadez" y los intentos de poner orden, junto con la vigorización de una hermandad a mediados del XVIII, la Sacramental, en orden a buscar una exclusividad social, nos deben plantear una relativización de las relaciones sociales del momento, que no debieron ser tan encorsetadas como se pretendió que fueran. Evidentemente, la fiesta siempre era un momento de cohesión social y relajación 
y, sin que llegaran a romperse las jerarquías, "actuaban como actuaban como atenuantes y medio de liberación de las tensiones sociales" ${ }^{" 53}$ Especialmente evidente fue en el caso de las fiestas de la Candelaria donde hay ejemplos de tolerancia y convivencia entre diversas castas ${ }^{54}$ algo que no ocurría en celebraciones representativas como el caso del Corpus pero donde quedaba reflejada la dificultad de establecer la disciplina jerárquica. La propia estructura social de la ciudad, marcada por una importante población flotante, puede explicar esta circunstancia en la que la élite permanente se vería sobrepasada por una población ajena a la ciudad, poco interesada en el mantenimiento de un apretado orden social. En este sentido hay que remarcar que entre los prebendados existía el sentimiento de considerar a los miembros del cabildo como recién llegados, ${ }^{55}$ los mismos prebendados que apelaban al arraigo a la ciudad para presentarse como defensores de la fiesta.

Aunque la documentación es muy limitada para tan largo periodo de tiempo, nos muestra a grandes rasgos la evolución de una fiesta que fue orgullo de la ciudad y por tanto su mejor escaparate. El estudio de más documentación nos puede acercar más a entender cómo fueron las relaciones sociales entre diversos grupos así como su interacción entre las distintas instituciones de gobierno. Durante el siglo XVIII la sociedad cartagenera fue evolucionando hasta aparecer una élite criolla que tenía su origen, primero en familias militares, ${ }^{56}$ y después, en familias de comerciantes,${ }^{57}$ que entroncaron en ambos casos con las antiguas familias locales. Por tanto, tuvieron que buscar nuevos símbolos de estatus entre los que no podían faltar la pertenencia a cofradías que debían hacerlos visibles en las oportunidades de exposición social que la fiesta representaba. Aun así, queda mucho por hacer en la búsqueda de documentación relativa a organizaciones corporativas, como cofradías, que puedan dar más luz sobre el asunto.

\footnotetext{
${ }^{53} \mathrm{M}^{\mathrm{a}}$ Teresa Ripoll, La élite en Cartagena y su tránsito a la República. Renovación política sin renovación social, Bogotá, Uniandes-Ceso, 2006, p. 11.

${ }^{54}$ C. Aschner Restrepo, "La música en las Fiestas y Celebraciones del Caribe colombiano, siglos XVII y XVIII”, en Memoria y Sociedad, vol. 9, n. 18, 2015, p. 85.

${ }_{55}$ Manuel Serrano García, El obispado de Cartagena de Indias durante el siglo XVIII. Iglesia y poder en la Cartagena colonial, tesis doctoral, Sevilla, 2015, p. 202.

${ }^{56}$ Carmen Gómez Pérez, "El Consulado de Sevilla y la formación de las oligarquías en Cartagena de Indias a principios del XVIII" en Andalucía y América en el siglo XVIII, Actas de las IV Jornadas de Andalucía y América, Sevilla, 1985, pp. 344-245.

57 Julián R. Ruiz Rivera, "Élites en Cartagena a finales del siglo XVIII”, en Luis Navarro García (coord.) Élites urbanas en Hispanoamérica: de la conquista a la independencia. Sevilla, Universidad de Sevilla, 2005, p. 294.
} 


\section{Bibliografía}

\section{Fuentes primarias:}

Archivo General de la Nación (Bogotá, Colombia) (AGN) Sección Colonia (SC), Historiaeclesiástica (HE), 6, d.25.

Archivo General de Indias (Sevilla, España) (AGI), Santa Fe, 228, n. 78 a.

AGI, Santa Fe, 489, n.12.

AGI, Santa Fe, 489, n. 19.

AGI, Santa Fe, 1034, n. 15.

AGI, Santa Fe, 1034, n. 12.

AGN, SC, HE, 14, d. 2.

Cordovez Moure, José María, Reminiscencias de Santafé y Bogotá, Bogotá, Fundación editorial Epígrafe, 2006.

Urueta, José P. Documentos para la historia de Cartagena. Cartagena: Tipografía de Antonio Araujo L., 1887-1891.

Zamora, Alonso de, Historia de la provincia de San Antonio del Nuevo Reino de Granada. Bototá: A.B.C., 1945.

\section{Fuentes secundarias:}

Aschner Restrepo, Camila, "La música en las Fiestas y Celebraciones del Caribe colombiano, siglos XVII y XVIII”, en Memoria y Sociedad, vol. 9, nº. 18, Bogotá, Pontificia Universidad Javeriana, 2015, pp. 78-87.

Bridikhina, Eugenia, Theatrum mundi: Entramados del poder en Charcas colonial, Lima (Perú)/La Paz (Bolivia) Instituto Francés de Estudios Andinos, Plural editores, 2007.

Constantino Bayle, S.J., El culto al Santísimo en Indias, CSIC, Madrid, 1951

Curcio-Nagy, Linda, "Giants and Gypsies: Corpus Christi in Colonial México City", en William H. Beezley, Cheryl English Martin y Willian E. French (eds.) Rituals of Rule, Rituals of Resistence. Public Celebrations and Popular Culture in Mexico, SR. Books, Wilmington, Delaware, 1994, pp. 1-27.

Dean, Carolyne, Inka Bodies and the Body of Christ. Corpus Christi in Colonial Cuzco, Peru, Durham, Duke University Press, 1999.

Duarte, Carlos F., "Las fiestas del Corpus Christi en la Caracas Hispánica (tarasca, gigantes y diablitos)", Archivo español de arte, 64, n. ${ }^{\circ} 255,1991$, pp. 337-348.

Estenssoro, Juan Carlos, "Los bailes de los indios y el proyecto colonial”, en Revista Andina, n. ${ }^{\circ}$ 10, Cuzco, Centro Bartolomé de las Casas, 1992, pp. 353-404. 
Gómez Pérez, Carmen, "El Consulado de Sevilla y la formación de las oligarquías en Cartagena de Indias a principios del XVIII" en Andalucía y América en el siglo XVIII, Actas de las IV Jornadas de Andalucía y América, Sevilla, 1985, pp. 329-348.

Jiménez Carpio, Fernando, "Las danzas gitanas en el Corpus Christi entre los siglos XVI y XVII", en Amarí. Revista Cultural Gitana, n. ${ }^{\circ}$ 7, 2017.

Gómez Pérez, Carmen, "El Consulado de Sevilla y la formación de las oligarquías en Cartagena de Indias a principios del XVIII" en Andalucía y América en el siglo XVIII, Actas de las IV Jornadas de Andalucía y América, Sevilla, 1985, pp. 329-348.

Lara Romero, Héctor, Fiestas y Juegos en el Reino de la Nueva Granada. Siglos XVI-XVIII, Bogotá, Universidad Distrital Francisco José de Caldas, Consejo Latinoamericano de Ciencias Sociales, 2015.

Lemaitre, Eduardo, Historia General de Cartagena, vol. II, Bogotá, Banco de la República, 1983.

Maravall, Jose Antonio, La cultura del Barroco. Análisis de una estructura histórica, Barcelona, Ariel, 1975.

Marchena Fernández, J, "Sin temor de rey ni de Dios. Violencia, corrupción y crisis de autoridad en la Cartagena colonial", en Marchena, J y Kuethe, A, (eds), Soldados del rey. El ejército borbónico en América Colonial en vísperas de la independencia, Universidad Jaime I, Castellón, 2005, pp. 22-78.

Mínguez, Víctor; Rodríguez Moya, Inmaculada; González Tornel, Pablo; Chiva, Juan, La fiesta Barroca. Los Virreinatos Americanos. (1560-1808), Castellón de la Plana, Universitat Jaume I y Universidad de las Palmas de Gran Canaria, 2012.

Moliné, Antoinette, "Las dos caras de una custodia: una invención andina del Corpus Christi”, en Gerardo Fernández Juárez y Fernando Martínez Gil (coord.), La fiesta del Corpus Christi, Cuenca (España), Universidad de Castilla-La Mancha, 2002, pp. 347-361.

Pacheco, Juan Manuel, "Historia eclesiástica. La evangelización del nuevo mundo", en Historia extensa de Colombia, vol. XIII, t. I, Bogotá, ediciones Lerner, 1971.

Ripoll, $\mathrm{M}^{\mathrm{a}}$ Teresa, La élite en Cartagena y su tránsito a la República. Renovación política sin renovación social, Bogotá, Uniandes-Ceso, 2006.

Rodríguez-Becerra, Salvador, "El Corpus en Andalucía. De fiesta de poder a fiesta de la identidad", en Gerardo Fernández Juárez y Fernando Martínez Gil (coord.), La fiesta del Corpus Christi, Cuenca (España), Universidad de Castilla-La Mancha, 2002, pp. 383-398.

Ruiz Rivera, Julián R., "Élites en Cartagena a finales del siglo XVIII", en Luis Navarro García (coord.) Élites urbanas en Hispanoamérica: de la conquista a la independencia. Sevilla, Universidad de Sevilla, 2005, pp. 293-310.

Serrano García, Manuel, El obispado de Cartagena de Indias durante el siglo XVIII. Iglesia y poder en la Cartagena colonial, tesis doctoral, Sevilla, 2015.

Sigaut, Nelly, "Corpus Christi: la construcción simbólica de la ciudad de México", en Víctor Mínguez (ed.), Del libro de emblemas a la ciudad simbólica, vol. I, Castellón, Univerisitat Jaume I, 2000, pp. 27-57.

Soto Hernández, Jairo Henrique, El Diablo en la Cultura Popular del Caribe Colombiano. Del Corpus Christi al Carnaval de Barranquilla, Barranquilla, Editorial La Iguana Ciega, 2012.

Valenzuela Márquez, Jaime, Las liturgias del poder: celebraciones públicas y estrategias persuasivas en Chile colonial (1609-1709), Santiago, Chile, LOM, 2001. 